\title{
Maternal behavior and early behavioral ontogeny of the Mediterranean monk seal Monachus monachus in Greece
}

\author{
Alexandros A. Karamanlidis ${ }^{1, *}$, Panagiotis Dendrinos ${ }^{1}$, Fritz Trillmich ${ }^{2}$ \\ ${ }^{1}$ MOm/Hellenic Society for the Study and Protection of the Monk Seal, 10682 Athens, Greece \\ ${ }^{2}$ University of Bielefeld, Animal Behavior, 33615 Bielefeld, Germany
}

\begin{abstract}
Understanding behavioral ontogeny is important for the successful conservation of endangered marine mammals. This is particularly the case for phocid seals, as during the early stages of their life they must acquire, largely independently, essential survival skills. We studied the maternal behavior and early behavioral ontogeny of the Mediterranean monk seal, one of the most endangered marine mammals on Earth, by installing a remote-controlled, infrared, video system in a pupping cave in Greece and recording the behavior of 2 adult females and their newborn pups (September 2007 to March 2008). Behavioral observations focused on the monitoring of individual attendance (i.e. percentage of time spent in attendance and attendance time) and the description of interactions. Following parturition, the percentage of time spent in attendance of both mothers and pups decreased gradually as pups developed towards independence. Overall, the pupping cave was used almost continuously by the 4 individuals for 3 to $4 \mathrm{mo}$. Similarly, attendance times also decreased after parturition. During the first $10 \mathrm{~d}$ postpartum, maternal attendance was followed by a 0.5 to $13.8 \mathrm{~h}$ absence, during which we presume that the adult females went out foraging. We also detail various in-cave interactions for the first time in Mediterranean monk seals in Greece, including lactations, interactions between mothers and pups, interactions between pups and general seal interactions. Our study increases our understanding of the in-cave behavior of the Mediterranean monk seal, while highlighting the vital role of suitable caves in the reproduction and survival of the species and the necessity to effectively protect this type of habitat.
\end{abstract}

KEY WORDS: Habitat use - Maternal attendance - Monachus monachus - Pupping cave · Species conservation

\section{INTRODUCTION}

Behavioral ecology and individual behavioral variation have been identified as important issues for the successful conservation of endangered marine mammals (Brakes \& Dall 2016). In the case of seals (i.e. Clade Pinnipedia; Families Odobenidae, Otariidae and Phocidae), their behavior has received considerable scientific attention, with most research efforts focusing on adults (Bowen 1991). Comparatively, less effort has been invested in illuminating aspects of the

*Corresponding author: akaramanlidis@gmail.com early behavioral ontogeny of seals and the relevant maternal behavior (Kovacs 1987, Trillmich 1990, 1996). However, understanding the behavior of seals, especially phocid seals, during the early stages of their life is important, as during this time they must acquire, largely independently (Blanchet et al. 2016), essential survival skills (e.g. diving and swimming; Horning \& Trillmich 1997, Watanabe et al. 2009, Jeglinski et al. 2012). At the same time, maternal behavior plays a key role in reproductive success (Kretzmann et al. 1993) and, consequently, species survival.

() The authors 2021. Open Access under Creative Commons by Attribution Licence. Use, distribution and reproduction are unrestricted. Authors and original publication must be credited. 
The Mediterranean monk seal Monachus monachus is arguably the most endangered pinniped in the world (Karamanlidis \& Dendrinos 2015) and a flagship species for marine conservation. Following centuries of human persecution and habitat loss, the species has been extirpated from most of its historical range and survives in 3 small, isolated subpopulations: 2 in the northeastern Atlantic (i.e. Cabo Blanco and archipelago of Madeira) and 1 in the eastern Mediterranean Sea (Karamanlidis et al. 2016). The latter subpopulation currently comprises more than $90 \%$ of the species' area of occupancy, is estimated to number approximately 400 individuals and has been a focal point of systematic research and conservation efforts since the early 1990s (Karamanlidis et al. 2019, Dendrinos et al. 2020).

Mediterranean monk seals are sexually dimorphic, moderately polygynous pinnipeds, which rest, give birth and raise their offspring in difficult-to-access marine caves (Karamanlidis et al. 2016). This behavior is believed to be an adaptation to the intense persecution by humans over the centuries (González 2015, Karamanlidis et al. 2016). As weaning of pups occurs at 4 to 5 mo of age (Pastor \& Aguilar 2003, Aguilar et al. 2007, Dendrinos 2011), Mediterranean monk seals spend a considerable part of their life within these marine caves. The inaccessibility of this habitat has, in comparison to other pinnipeds, limited our understanding of early mother-pup interactions and the development of pup behavior. Such behaviors and interactions have been systematically studied only in the Mediterranean monk seal subpopulation in Cabo Blanco (Pastor \& Aguilar 2003, Aguilar et al. 2007); in the subpopulation in the eastern Mediterranean, the in-cave social behavior of the species is poorly understood and restricted to a small number of circumstantial observations from Greece (Dendrinos et al. 2007b, Karamanlidis et al. 2010, Dendrinos 2011, Karamanlidis et al. 2013) and Turkey (Mursaloğlu 1986).

Given the marked differences in demographics, ecology and behavior between the monk seals in the Atlantic and the eastern Mediterranean (Karamanlidis et al. 2016), a more thorough description of the maternal behavior and early behavioral ontogeny of Mediterranean monk seals in the eastern Mediterranean is of interest for understanding the species' behavior and for developing relevant conservation measures.

\section{MATERIALS AND METHODS}

\subsection{Study site and monitoring technology}

Behavioral observations were carried out in a marine cave at the island of Kimolos, southwestern Cyclades islands (3649'25.4" N, 243' $\left.14.4^{\prime \prime} \mathrm{E}\right)$. The cave has an entrance facing to the east and a $35 \mathrm{~m}$ long corridor leading to a pool covering approximately $100 \mathrm{~m}^{2}$ and a sand/pebble beach that is separated by a rock ledge into 2 smaller beaches. This beach is almost completely washed out during storms and offers a maximum of approximately $50 \mathrm{~m}^{2}$ dry area during calm weather (Fig. 1).

A remote-controlled monitoring system was installed in the cave at a time when no seals were present. The location of the monitoring system and the fact that it was remote-controlled allowed us to monitor the entire beach area and a large part of the inner pool (i.e. the part where the majority of events during the early stages of a pup's life occur) of the cave. The system consisted of a digital video camera
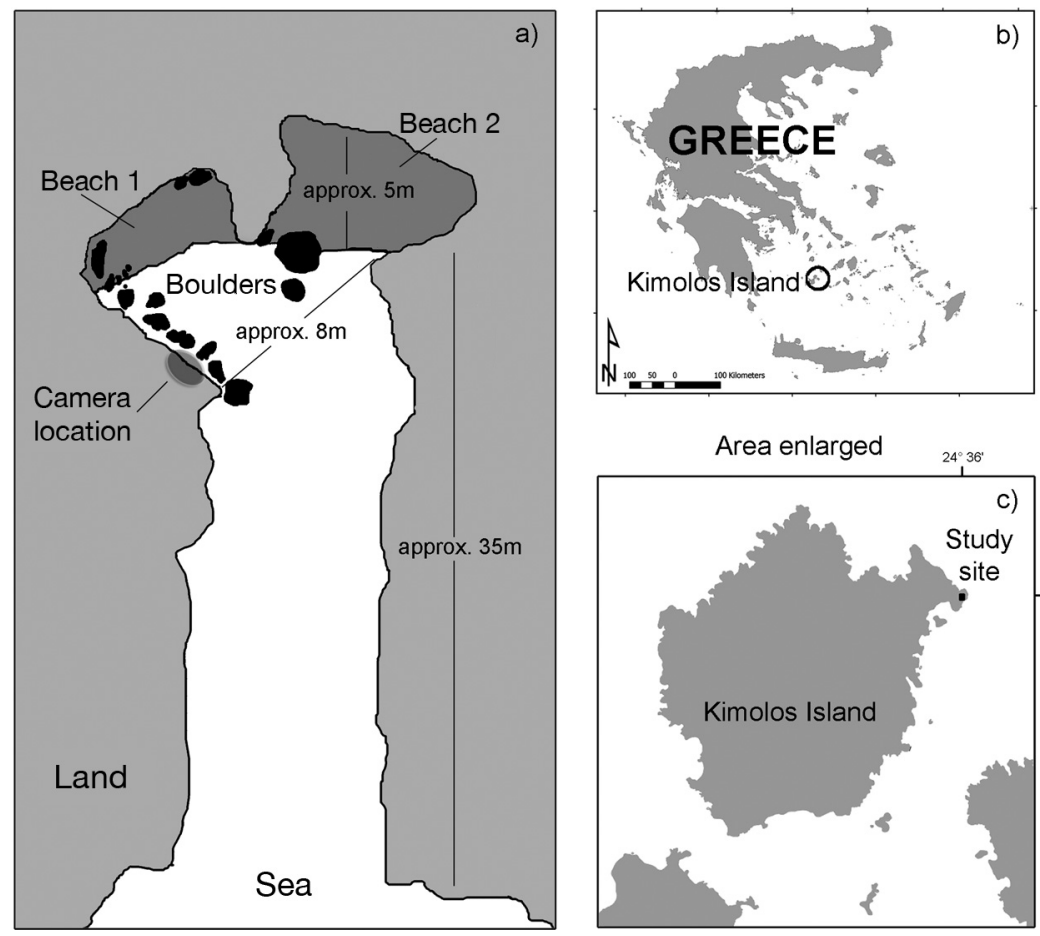

Fig. 1. (a) The study site indicating the main topographic features of the cave; the drawing is not to scale. (b) Location of the general study area in Greece. (c) Location of the study site on Kimolos Island 
(AU-G70, VIDO Electronics) and 2 infrared light beams $(140 \mathrm{~W})$ that potentially enabled $24 \mathrm{~h}$ monitoring. The system was powered by 12 solar panels (1400 W), which charged a set of 4 car batteries. The camera was programmed to make video recordings (termed 'behavioral observations') of $4 \mathrm{~min} 30 \mathrm{~s}$ out of every 5 min interval.

\subsection{Behavioral observations}

Behavioral observations were carried out from September 2007 to March 2008 on 2 monk seal pups born in the cave (i.e. 'Kamerata', a female born on September 19, 2007 and 'Alex', a male born on October 2, 2007; see Karamanlidis et al. 2010) and their mothers. Pups were initially identified by their sexually dimorphic belly patches (Badosa et al. 1998). Following the first molt, when the juvenile pelage generally does not allow pups to be distinguished, pup identification was based on their relative size when observed together, or else on the identification of their mothers and the assumption that mothers would only suckle their own pups (however, for allo-suckling of monk seal pups in Greece see Karamanlidis et al. 2013). Individual recognition of adult females was based on scars and pelage patterns (Forcada \& Aguilar 2000).

Behavioral observations included the monitoring of individual attendance and behavior. For individual attendance (i.e. presence of individuals within the field of view of the camera) we recorded attendance times, and from that measure we then calculated the proportion of time an animal was in attendance (expressed as 'Percentage in attendance'). Attendance times were defined as the consecutive time of an animal ashore. We recorded attendance as continuous if an absence, i.e. in the water and not within the field of view of the camera, did not last longer than 3 consecutive videos (i.e. $15 \mathrm{~min}$ ). When a mother was in the water in contact with her pup this was also recorded as 'in attendance'.

Considering that the camera occasionally failed and that, as a result, sometimes only parts of a given day were monitored (Fig. A1), we calculated 'Percentage in attendance' relative to the daily total recording time of the camera. In January 2008, video records were very incomplete for many days; we therefore selected January 9-13 and 18-22 that were almost complete to record individual percentage in attendance. Two 5 d periods in February (1-5 and 19-23) and 2 in March (1-5 and 16-20), for which the video records were also almost complete (Fig. A1), were corre- spondingly selected to document individual percentage in attendance in February and March.

Behavioral observations were classified as interacting, active or resting. Interactions (i.e. animals less than half a pup body length apart) were classified as in proximity/contact or suckling (searching for a teat, as well as presumed suckling). For each behavioral observation, we recorded just 1 behavior: as we were mainly interested in understanding mother-pup interactions, we classified a 4.5 min video sequence as 'Suckling' regardless of which other behaviors might have been occurring at the same time. Suckling was measured in 5 min periods, so that a lactation event observed during 3 subsequent videos was recorded as $15 \mathrm{~min}$. If interactions other than suckling occurred during a video sequence, this was recorded as 'Interaction' and the interaction partner was noted. If an animal showed activity alone or further away than half a body length from another animal, either on land or at sea, this was classified as 'Activity'. When no movement was observed during a video sequence, this was classified as 'Resting'.

\section{RESULTS AND DISCUSSION}

Following parturition, 'Percentage in attendance' of both mothers and pups decreased gradually as pups developed towards independence. In February to March 2008 (i.e. approximately from Day 125 following the birth of Kamerata), none of the animals were observed in the cave (Fig. 2). Overall, the pupping cave was used almost continuously by the 4 individuals for 3 to $4 \mathrm{mo}$ : Kamerata was last recorded at her natal site when she was 125 d old, Alex when he was 112 d old. Kamerata's mother was last seen using the pupping cave with Kamerata when her pup was $96 \mathrm{~d}$ old, while Alex's mother was last seen when her pup was 112 d old. These observations are in accordance with behavioral observations from the Northern Sporades Islands, Greece (Dendrinos 2011) and Turkey (Mursaloğlu 1986), and highlight the vital importance of suitable pupping caves in the reproductive behavior of the Mediterranean monk seal (Dendrinos et al. 2007a). It should be noted that during the 3 to 4 mo continuous monitoring period, Kamerata and her mother were once absent from the cave for about $3 \mathrm{~d}$ (pup not observed for $63.2 \mathrm{~h}$; mother for $92.7 \mathrm{~h}$ ), and Alex and his mother were once absent for a long period of time (i.e. approximately $101 \mathrm{~h}$ at the end of October) and another 4 times for more than $20 \mathrm{~h}$. This suggests the use of an alternative marine cave and, more specifi- 


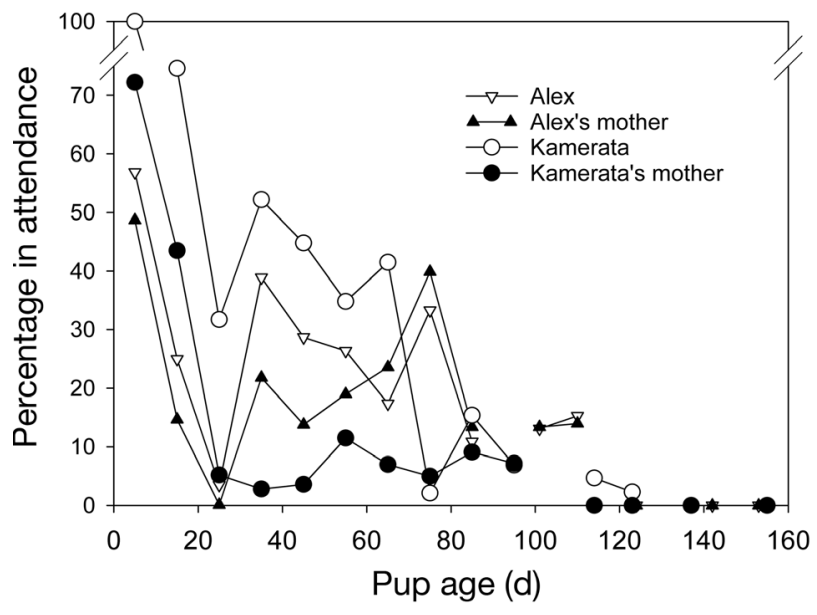

Fig. 2. Individual percentage of time spent in attendance (percentage in attendance; $10 \mathrm{~d}$ averages) of 4 Mediterranean monk seals in a pupping cave in Greece. Attendance times were defined as the consecutive time of an animal ashore

cally, of an adjacent cave, the underwater entrance of which is only $30 \mathrm{~m}$ away from the entrance of our study site. The occasional use of this secondary cave by mother-pup pairs has been confirmed during previous years through direct observations. In our study we found no recognizable connection between absence from the cave and unfavorable weather. However, alternative caves have been suggested to provide refuge during times of unfavorable weather conditions (Dendrinos 2011) and likely play an important role in lowering neonatal mortality. It should be noted that, in our region, neonatal mortality is assumed to be lower than that recorded in the Cabo Blanco subpopulation. This may be due to the availability of alternative resting caves differing in their exposure to inclement weather.

Following parturition, Kamerata's mother stayed with her pup continuously for $112.5 \mathrm{~h}$, while Alex's mother stayed with her pup for 44 and $64 \mathrm{~h}$, interrupted by a $3.6 \mathrm{~h}$ absence. Thereafter, and within the first $10 \mathrm{~d}$ postpartum, attendance times decreased considerably to a daily mean of $13.6 \mathrm{~h}$ in the case of Kamerata's mother and $0.6 \mathrm{~h}$ in that of Alex's mother. When the mothers were in attendance at the beach, they were almost always in direct contact with their pup (Video S1 in the Supplement at www. int-res.com/articles/suppl/n045p013_supp/). Between 10 and $90 \mathrm{~d}$ postpartum, the individual attendance time of Kamerata's mother decreased further to a mean of $5.2 \mathrm{~h}$ (Fig. 3c), while that of Alex's mother increased to $4.1 \mathrm{~h}$ (Fig. 3d). During the first $10 \mathrm{~d}$ postpartum, maternal attendance was followed by a 0.5 to $13.8 \mathrm{~h}$ absence, during which we presume that the adult females went out foraging (Kamerata's mother: $\mathrm{N}=6$, duration $=8.0 \pm 3.3 \mathrm{~h}[\text { mean } \pm \mathrm{SD}]_{;}$Alex's mother: $\mathrm{N}=9$, duration $=3.6 \pm 2.8 \mathrm{~h}$ ). There was no observable trend in lengthening or shortening of absence durations during the first $10 \mathrm{~d}$ after parturition. A similar behavior of alternating pup attendance and regular absences for foraging has been recorded in the subpopulation at Cabo Blanco (Gazo \& Aguilar 2005) and is in marked contrast to the closest relative of the species, the Hawaiian monk seal Neomonachus schauinslandi, where females generally do not leave their pups unattended and fast or feed rarely during lactation (Littnan et al. 2018). When counting attendance durations of $\geq 3 \mathrm{~h}$ only, Kamerata's mother attended her pup 12 times during the night and 14 times during the day, Alex's mother 7 times during the night and 16 times during the day. Thus, in our records, there was no recognizable trend for day or night foraging, or attendance with the pup.

We recorded various in-cave interactions, including lactations, interactions between mothers and pups, interactions between pups and general seal interactions.

Kamerata and Alex suckled (Video S1) between 5 and $35 \mathrm{~min}$, with a mean of $15 \mathrm{~min}$. This duration did not change substantially between the time intervals Days 1-10, 11-30 and 31-90 (Table 1), and did not show substantial difference between the 2 pups. Both pups were observed suckling for at least 3 mo (i.e. Kamerata was last observed suckling at an age of $96 d_{\text {; }}$ Alex was last observed suckling at an age of $109 \mathrm{~d})$, thus, partially confirming the unusual lactation pattern of the species (Aguilar et al. 2007) as being one of the longest for a phocid seal (Littnan et al. 2018). Kamerata was observed unattended in the pupping cave at the age of 115 to $125 \mathrm{~d}$. Although we cannot exclude the possibility of being totally weaned at this age, it appears more likely that Kamerata was in the transition period of actively feeding on her own, while simultaneously also suckling from her mother at another site (Kiraç \& Ok 2019).

Often, when a mother returned to the cave following a long period of absence, she would call her pup (as concluded from her lifting her head clear out of the water and widely opening her mouth once or several times) (Video S1). This would awaken her pup almost immediately, whereupon it would rush into the water to meet her. Individually distinct 'pup contact' calls have been studied extensively in colonial otariids; however, they also exist in phocid seals, such as Weddell seals Leptonychotes weddellii (Collins et al. 2005). Individually distinct call types have also been recorded in Mediterranean monk seals 

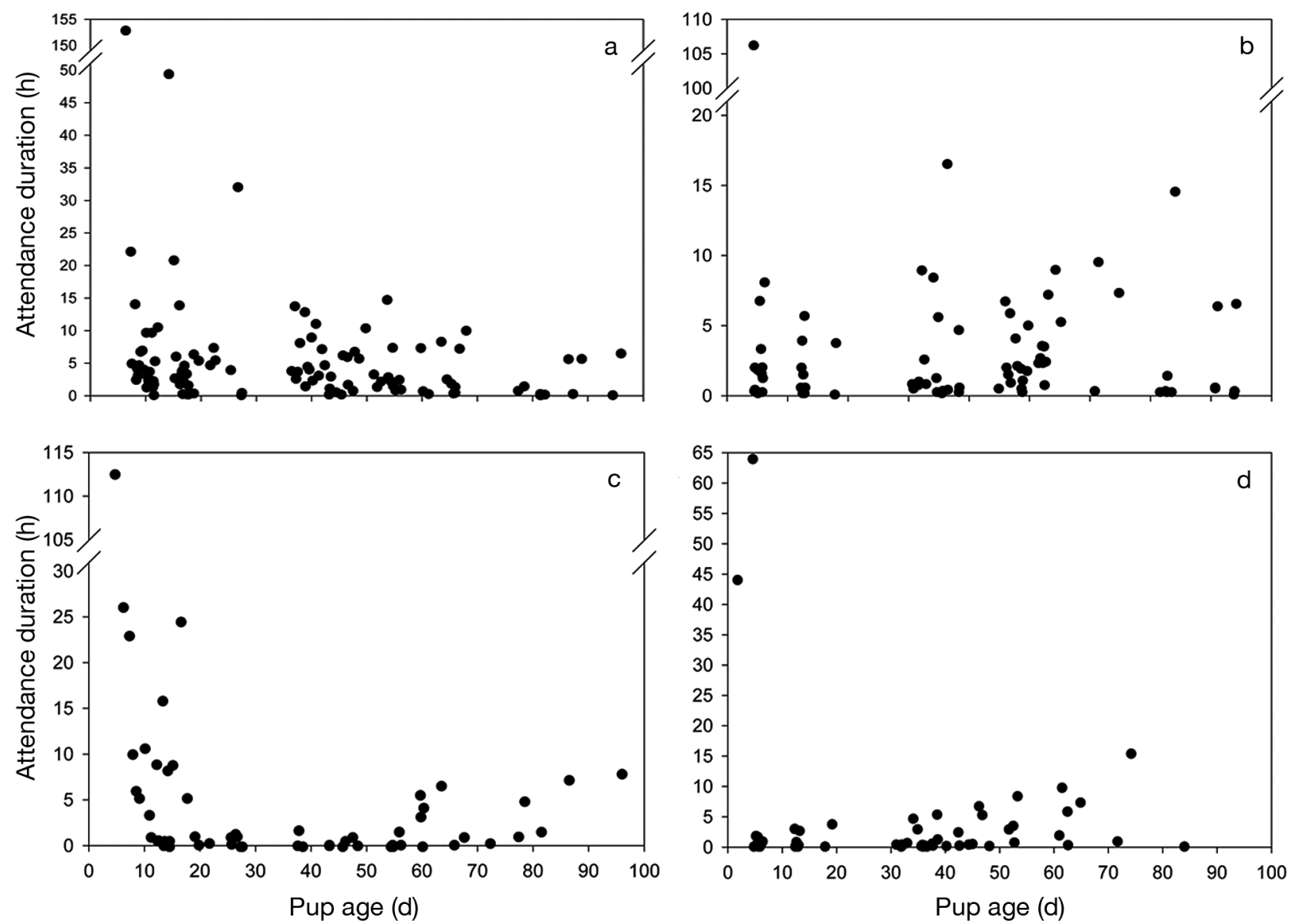

Fig. 3. Individual attendance times of 4 Mediterranean monk seals in a pupping cave in Greece. (a) Kamerata, (b) Alex, (c) Kamerata's mother, (d) Alex's mother

Table 1. Suckling duration (estimated to the nearest $5 \mathrm{~min}$ ) of 2 Mediterranean monk seal pups in Greece

\begin{tabular}{|llrllc|}
\hline \multirow{2}{*}{$\begin{array}{l}\text { Age } \\
\text { (d) }\end{array}$} & Mean \pm SD & $\begin{array}{c}\text { Sample } \\
\text { size }\end{array}$ & & Mean \pm SD & $\begin{array}{c}\text { Sample } \\
\text { size }\end{array}$ \\
\hline $1-10$ & $15.4 \pm 6.3$ & 25 & & $15.0 \pm 5.7$ & 27 \\
$11-30$ & $13.8 \pm 11.8$ & 4 & & $13.9 \pm 7.1$ & 23 \\
$31-90$ & $16.1 \pm 9.0$ & 35 & & $15.1 \pm 12.8$ & 16 \\
\hline
\end{tabular}

(Charrier et al. 2017) and likely play an important role in mother-pup recognition in the dark environment of the marine caves the species occupies. Upon reunion, mothers and pups often interacted with each other by nuzzling each other's nose and face (Video S1). Nuzzling has also been recorded in monk seals in Cabo Blanco (Layna et al. 1999) and is a behavior that is not uncommon in phocid and otariid seals (Rogers et al. 2005). Nuzzling is associated with olfactory discrimination, which appears to be well developed, at least in otariids (Pitcher et al. 2011, Kim et al. 2013, Wierucka et al. 2019). This reunion sometimes led to both animals spending longer periods of time in the water, at the entrance of the cave. At other times, both animals would move onto the beach where they would rest side by side or lactation would ensue. When a mother rested for longer periods at the beach, her pup would generally rest beside her. When a mother was approached by a non-filial pup, this resulted in a short contact, but usually no further reaction was recorded. On rare occasions, however, the approach of a non-filial pup led to visible aggression. Kamerata's mother reacted once (out of a total of 9 direct body contacts) mildly aggressively (i.e. open mouth threat) towards Alex, while Alex's mother threatened Kamerata on 3 occasions (out of a total of 10 interactions) (Video S1). Most aggressive interactions were recorded when the pups were still young, between October 1 and 15. Aggressive interactions in the pupping caves between females and pups have also been recorded 
previously in Greece (Karamanlidis et al. 2013). Finally, during bad weather conditions, females tried to protect their newborns by placing their bodies between their pups and the incoming waves (Video S1).

As soon as the swimming skills of both pups were well developed, they interacted intensely (Video S1), following each other or swimming in circles about each other, apparently trying to grab the other one by its rear or front flippers. It should be noted that, as in the subpopulation in Cabo Blanco, pup swimming/ diving performance increased progressively with age (Gazo et al. 2006). Kamerata went into the water on Day 6 of her life and spent longer periods of time, up to an hour, swimming around, even in the absence of her mother. Alex went into the water even earlier, already on Day 3 of his life. Pup time in the water away from the cave beach increased with pup age (Kamerata: time absent $=0.041 \times$ age in days + $0.614 ; R^{2}=0.197, p<0.01$; Alex: time absent $=0.095$ $\times$ age in days $+0.397 ; \mathrm{R}^{2}=0.155 ; \mathrm{p}<0.01$ ) (Fig. 4 ) .

When the mothers met, they largely ignored each other or behaved passively. For example, on October 5, Kamerata's mother rested her head or hind flippers on the body of Alex's mother for nearly $10 \mathrm{~h}$ while both were attending their pups, without any clear reaction of the latter (Video S1). Juveniles (of undetermined sex) were recorded in the cave on 6 occasions, mostly in early November. They spent most of the time in the water in front of the beach and interacted very little with the 4 focal animals. All observed interactions consisted of brief contacts, except for 1 juvenile that interacted intensely for about half an hour on November 3 with Alex's mother (Video S1). The juvenile repeatedly crawled over Alex's mother and made nose to nose contact without elicit- ing any aggressive reaction from her. Aggressive incave interactions between adult females and other seals have been recorded throughout the range of the species (Layna et al. 1999, Dendrinos et al. 2007b) and are likely related to a number of factors, including available resting space in the cave and the social status of the animals interacting. Finally, males entered the cave only 3 times (i.e. once in November and twice in January), when the focal animals were not present (Video S1). They rested for a short time and then disappeared again. Mating in the Mediterranean monk seal takes place at sea and adult males defend aquatic territories (Pastor et al. 2011), thus making them much less dependent on good resting caves (i.e. sensu Dendrinos et al. 2007a). Male monk seals have therefore often been observed to also rest/sleep in the water (Karamanlidis et al. 2017).

Our study provides unique insights into and increases our understanding of the in-cave behavior of the Mediterranean monk seal in the eastern Mediterranean. It also highlights the vital role of suitable pupping caves in the reproduction and survival of the species. According to the new 'Action Plan for the Mediterranean monk seal in Greece', one of the main conservation priorities for the species in the country is the identification and effective protection by the Hellenic State authorities of all suitable monk seal pupping sites (Dendrinos et al. 2020).

Acknowledgements. This study was carried out as part of the project 'Innovative application of new technologies in the protection of the Mediterranean monk seal \& promotion of the natural environment of the island of Kimolos' of the EU funding scheme LEADER+ 2000-2006. We thank the people of Kimolos for their hospitality and support in the efforts to protect the endangered Mediterranean monk seal
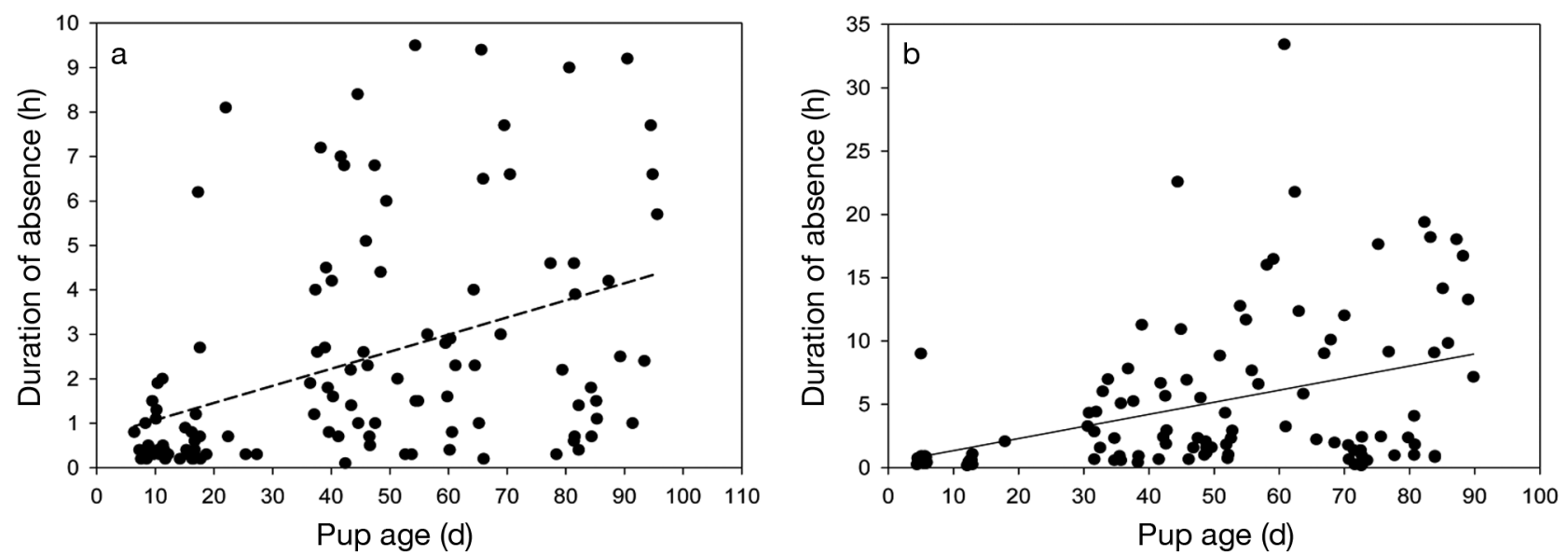

Fig. 4. Duration of absence (i.e. time in the water or resting in a nearby cave) for 2 Mediterranean monk seal pups. (a) Kamerata, (b) Alex (absences longer than $100 \mathrm{~h}$ were excluded) 
and especially the artisanal fisherman Charalampos Sardis for his logistic support during the installation of the cave monitoring system. We also thank $\mathrm{H}$. Marsh and 3 anonymous reviewers for constructive comments that improved the quality of our manuscript.

\section{LITERATURE CITED}

Aguilar A, Cappozzo LH, Gazo M, Pastor T, Forcada J, Grau E (2007) Lactation and mother-pup behaviour in the Mediterranean monk seal Monachus monachus: an unusual pattern for a phocid. J Mar Biol Assoc UK 87:93-99

Badosa E, Grau E, Aparicio F, Layna JF, Cedenilla MA (1998) Individual variation and sexual dimorphism of coloration in Mediterranean monk seal pups (Monachus monachus). Mar Mamm Sci 14:390-393

Blanchet MA, Lydersen C, Ims RA, Kovacs KM (2016) Making it through the first year: ontogeny of movement and diving behavior in harbor seals from Svalbard, Norway. Mar Mamm Sci 32:1340-1369

Bowen WD (1991) Behavioural ecology of pinniped neonates. In: Renouf D (ed) The behaviour of pinnipeds. Springer, Dordrecht, p 66-127

Brakes P, Dall SR (2016) Marine mammal behavior: a review of conservation implications. Front Mar Sci 3:87

* Charrier I, Marchesseau S, Dendrinos P, Tounta E, Karamanlidis AA (2017) Individual signatures in the vocal repertoire of the endangered Mediterranean monk seal: new perspectives for population monitoring. Endang Species Res 32:459-470

Collins KT, Rogers TL, Terhune JM, McGreevy PD, Wheatley KE, Harcourt RG (2005) Individual variation of in-air female 'pup contact' calls in Weddell seals, Leptonychotes weddellii. Behaviour 142:167-189

Dendrinos P (2011) Contribution to the study of the Mediterranean monk seal's (Monachus monachus) ecology and biology at the island complex of Northern Sporades, Greece. PhD thesis, National and Kapodistrian University of Athens

Dendrinos P, Karamanlidis AA, Kotomatas S, Legakis A, Tounta E, Matthiopoulos J (2007a) Pupping habitat use in the Mediterranean monk seal: a long-term study. Mar Mamm Sci 23:615-628

Dendrinos P, Tounta E, Karamanlidis AA, Legakis A, Kotomatas S (2007b) A video surveillance system for monitoring the endangered Mediterranean monk seal (Monachus monachus). Aquat Mamm 33:179-184

Dendrinos D, Karamanlidis AA, Adamantopoulou S, Koemtzopoulos K, Komninou A, Tounta E (2020) LIFE-IP 4 NATURA: Integrated actions for the conservation and management of Natura 2000 sites, species, habitats and ecosystems in Greece. Deliverable Action A.1: Action Plan for the Mediterranean monk seal (Monachus monachus). Hellenic Ministry of Environment and Energy, Athens

Forcada J, Aguilar A (2000) Use of photographic identification in capture-recapture studies of Mediterranean monk seals. Mar Mamm Sci 16:767-793

*Gazo M, Aguilar A (2005) Maternal attendance and diving behavior of a lactating Mediterranean monk seal. Mar Mamm Sci 21:340-345

Gazo M, Lydersen C, Aguilar A (2006) Diving behaviour of Mediterranean monk seal pups during lactation and post weaning. Mar Ecol Prog Ser 308:303-309
González LM (2015) Prehistoric and historic distributions of the critically endangered Mediterranean monk seal (Monachus monachus) in the eastern Atlantic. Mar Mamm Sci 31:1168-1192

*Horning M, Trillmich F (1997) Ontogeny of diving behaviour in the Galapagos fur seal. Behaviour 134:1211-1257

* Jeglinski JWE, Werner C, Robinson PW, Costa DP, Trillmich F (2012) Age, body mass and environmental variation shape the foraging ontogeny of Galapagos sea lions. Mar Ecol Prog Ser 453:279-296

Karamanlidis AA, Dendrinos P (2015) Monachus monachus. The IUCN Red List of Threatened Species 2015:e.T13653 A45227543. https://dx.doi.org/10.2305/IUCN.UK.2015-4. RLTS.T13624A45227543.en (accessed on 6 January 2021)

Karamanlidis AA, Paravas V, Trillmich F, Dendrinos P (2010) First observations of parturition and postpartum behavior in the Mediterranean monk seal (Monachus monachus) in the Eastern Mediterranean. Aquat Mamm 36:27-32

Karamanlidis AA, Adamantopoulou S, Paravas V, Psaradellis M, Dendrinos P (2013) Demographic structure and social behavior of the unique Mediterranean monk seal colony of the island of Gyaros. In: Proc 20th Biennial Conf Biology of Marine Mammals, 9-13 December 2013, Dunedin, Society for Marine Mammalogy:110

* Karamanlidis AA, Dendrinos P, Fernández de Larrinoa P, Gücü AC, Johnson WM, Kiraç CO, Pires R (2016) The Mediterranean monk seal Monachus monachus: status, biology, threats, and conservation priorities. Mammal Rev 46:92-105

Karamanlidis AA, Lyamin O, Adamantopoulou S, Dendrinos $P$ (2017) First observations of aquatic sleep in the Mediterranean monk seal (Monachus monachus). Aquat Mamm 43:82-86

Karamanlidis AA, Adamantopoulou S, Tounta E, Dendrinos D (2019) Monachus monachus Eastern Mediterranean subpopulation. The IUCN Red List of Threatened Species 2019:e.T120868935A120869697. https://dx.doi.org/ 10.2305/IUCN.UK.2019-1.RLTS.T120868935A120869697. en (accessed on 6 January 2021)

K Kim S, Amundin M, Laska M (2013) Olfactory discrimination ability of South African fur seals (Arctocephalus pusillus) for enantiomers. J Comp Physiol A Neuroethol Sens Neural Behav Physiol 199:535-544

*Kiraç CO, Ok M (2019) Diet of a Mediterranean monk seal Monachus monachus in a transitional post-weaning phase and its implications for the conservation of the species. Endang Species Res 39:315-320

Kovacs KM (1987) Maternal behavior and early behavioral ontogeny of grey seals (Halichoerus grypus) on the Isle of May, UK. J Zool (Lond) 213:697-715

Kretzmann MB, Costa DP, Leboeuf BJ (1993) Maternal energy investment in elephant seal pups: evidence for sexual equality. Am Nat 141:466-480

*ayna JE, Cedenilla MA, Aparicio F, Gonzalez LM (1999) Observations of parturition in the Mediterranean monk seal (Monachus monachus). Mar Mamm Sci 15:879-882

Littnan C, Karamanlidis AA, Dendrinos P (2018) Monk seals. Monachus monachus, Neomonachus schauinslandi and N. tropicalis. In: Wuersig B, Thewissen JGM, Kovacs KM (eds) Encyclopedia of marine mammals. Academic Press/Elsevier, San Diego, CA, p 618-622

Mursaloğlu B (1986) Pup-mother-environment relations in the Mediterranean monk seal, Monachus monachus (Hermann, 1779), on Turkish coasts. Commun Fac Sci Univ Ankara Ser C 4:1-8 
Pastor T, Aguilar A (2003) Reproductive cycle of the female Mediterranean monk seal in the western Sahara. Mar Mamm Sci 19:318-330

Pastor T, Cappozzo HL, Grau E, Amos W, Aguilar A (2011) The mating system of the Mediterranean monk seal in the Western Sahara. Mar Mamm Sci 27:E302-E320

Pitcher BJ, Harcourt RG, Schaal B, Charrier I (2011) Social olfaction in marine mammals: wild female Australian sea lions can identify their pup's scent. Biol Lett 7:60-62

Rogers TL, Collins KT, Harcourt RG, Wheatley KE, McGreevy PD, Terhune JM (2005) Individual variation of in-air female 'pup contact' calls in Weddell seals, Leptonychotes weddellii. Behaviour 142:167-189
Trillmich F (1990) The behavioral ecology of maternal effort in fur seals and sea lions. Behaviour 114:3-20

* Trillmich F (1996) Parental investment in pinnipeds. Adv Stud Behav 25:533-577

*Watanabe Y, Lydersen C, Sato K, Naito Y, Miyazaki N, Kovacs KM (2009) Diving behavior and swimming style of nursing bearded seal pups. Mar Ecol Prog Ser 380: 287-294

*Wierucka K, Barthes N, Harcourt R, Schaal B, Charrier I, Pitcher BJ (2019) Chemical fingerprints suggest direct familiarisation rather than phenotype matching during olfactory recognition in Australian sea lions (Neophoca cinerea). J Exp Mar Biol Ecol 517:49-53

Appendix.

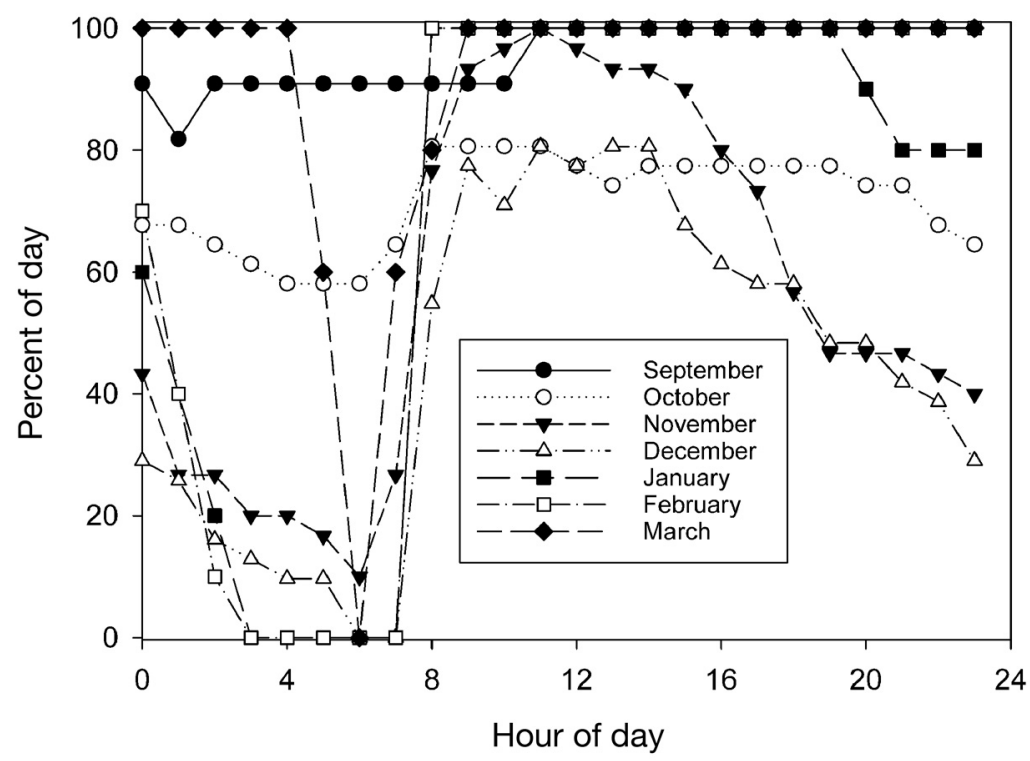

Fig. A1. Video coverage for all observation periods. The percentages of the specific daytime covered for the respective months or $5 \mathrm{~d}$ periods in January, February and March (see Section 2.2.) are presented. An hour was counted as covered when more than half of the given hour was covered by analyzable video material

Editorial responsibility: Helene Marsh,

Townsville, Queensland, Australia,

Reviewed by: 3 anonymous referees
Submitted: November 7, 2020

Accepted: January 18, 2021

Proofs received from author(s): May 2, 2021 